patients, and of 130 of these cancer patients under my own observation 11 had previously suffered from rheumatic fever and six from other rheumatic affections. My analysis showed 12 deaths from heart disease among 154 parents of breast cancer patients, or one in 128 , whereas in the general community at that time the corresponding ratio was one in 79. From rheumatic fever my analysis showed one death in 154 parents, whereas the corresponding ratio for the community was one in 197 .

As a concrete example of the connexity of these two morbid conditions I cited the case of the celebrated Bonaparte family, all the members of which were prone to arthritic manifestations. Pierre died from heart disease consequent on rheumatic fever and Napoleon III. died from stone in the bladder; two other members of the family-Jérôme and his son Napoleon-suffered from diabetes; finally, Napoleon I., his father, his brother Lucien, and his sisters Caroline and Pauline all died from cancer of the stomach. It is a long cry from such indications as the foregoing to the position lately taken up by Dr. Alexander Haig that an excess of uric acid in the tissues is the cause of cancer and it will be interesting to know the facts on which he bases his hypothesis.

Cancerous tumours consist almost exclusively of albuminous or proteid substances and it seems not unreasonable to suppose that they may be caused by excess of these sub stances in the body, and especially of such of them as serve as nuclear cabulum. When excessive quantities of such highly stimulating forms of nutriment are ingested by persons whose cellular metabolism is defective there may thus be excited in those parts of the body where vital pro cesses are most active such excessive and disorderly cellular prolifera!ion as may eventuate in cancer. However, this may be, I am persuaded that the ascertained facts justify the belief that there is a certain relation between the con ditions of existence-in which alimentation plays an important part-and the incidence of carcer.

I am, Sirs, yours faithfully,

Clifton, Bristol, June 20th, $1904 . \quad$ W. RoGeB Williams.

\section{THE SANDGATE SCANDAL.}

\section{To the Editors of THE LANOWT.}

SIRS, - I have long thought it imperative to warn patients coming to me as intending convalescents at the Bevan Memorial Home at Sandgate-across the road from "the Grosvenor" and other "homes" named in your article of June 11th-against the dangers necessarily arising from indiscriminate contact with these unfortunate tuberculous patients and their dejecta. May I therefore offer you my best thanks for your able advocacy of reform in this matter, of such serious importance not only to the ordinary in habitants of Sandgate but to convalescents in various stages of susceptibility and to the swarms of young soldiers from the neighbouring Shorncliffe camp.

I am, Sirs, yours faithfully,

ARThur J. HARRIES, M.D. Brux.

One of the honorary examining medical officers to the Alfred Bevan Memorial Convalescent Home.

St. James's-square, S.W., June 15th, 1904.

\section{NOTES FROM INDIA.}

\section{(From OUR SPECIAL CORRESPONDENT.)}

The Failure of Hydrocarbon as a Disinfectant.-The Plaque Epidemio.-Diplomas for Medioal Students.-The Pasteur Institute for Madras.

THE so-called hydrocarbon, one of the by-products in the manufacture of gas, was largely recommended as a suitable disinfectant for plague. Boomed in the Sonthern Mahratta country it received the support of at least one local government for extensive trials. Its reputed value has been completely negatived by a series of experiments undertaken by Lieutenant-Colonel W. B. Bannerman, I.M.S., when superintendent of the King's Institute at Guindy. The results show that it is useless and that it had no effect on even the mildest form of germs in culture. The danger attending its use was sufficient to condemn it from the outset and its applicability to almost fireproof places only renders it practically useless.

The mortality from plague throughout India shows an improvement. For the week ending May 21st 28,219 deaths were recorded, as compared with 35,413 for the previous seven days. These figures are double the numbers of last sear. The disease in its virulent form is almost entirely confined to the Punjab and the season's outbreak has subsided in nearly every other part of India. The Punjab recorded 24,853 deaths, as against 30,723 for the previous week. The peculiar feature of its incidence this year in the province is its more widespread character and the tendency which the outbreak has shown to be prolonged into the summer season. Other figures are: Bombay Province, 1086 deaths, as against 1653; United Provinces, 1069, as against 1303 ; Bengal, 215, as against 261 ; Rajputana, 195. as against 374 ; Central India, 109, as against 100 ; Central Provinces, 21, as against 62 ; Kashmir, 74, as against 221 ; Bombay city, 208, as against 265; Calcutta, 134 ; and Karachi, 77.

Now that Western medical education has become so extended amongst the natives of India and the governments of each province maintain and regulate medical schools it is about time that unauthorised institutions purporting to train medical students and granting diplomas should be abolished. The so-called College of Physicians and Surgeons of Calcutta bas recently issued a list of four candidates who are said to have passed for the final M.O.P.S. and a further list of about 22 students who have been successfal in the final L.C.P.S., together with a full notification of those who have gained honours. The young men who have wasted their money in this course are to be pitied. Even supposing that the diplomas were deservedly obtained in each individual case there is no criterion of any standard of medical knowledge. At the present time the variety of practitioners is hopelessly confusing and the value of the numerous qualifications in Great Britain is clear compared with the very mixed list displayed in every Indian city.

The Pasteur Institute for Madras will probably be at Coonoor. A site has been selected and only awaits formal sanction. It will be worked on the lines of the Kasauli Institute.

June 2nd.

\section{A SHORT STATEMENT OF THE LAW RELATING TO THE SALE OF MEDICAL PRACTICES.}

\section{(By a Barrister.)}

THE instructive decision given by the Court of Appeal in the recent case of Robertson $v$. Buchanan, which arose out of the sale of the goodwill of a medical practice, is a decision which should be carefully noted by every medical practitioner who is a potential vendor or purchaser of a practice. The misunderstanding which arose here is an object lesson of the necessity-daily exemplified in every court in the landof parties to a contemplated contract arriving at a clear understanding before, and not after, they set their seals to their agreements. In this case of Robertson $v$. Buchanan the material facts were briefly as follows. In 1901 the defendant sold the goodwill, \&c., of his practice in Brixton to the plaintiff for the sum of $£ 750$ and at the same time covenanted that he would "not for a period of ten years computed from the 14th Feb. last, except with the consent of the said J. R., set up in practice as a physician and surgeon, either alone or jointly with any person whomsoever, within the distance (as the crow flies) of two miles of 337 , Brixton-road." In 1903 the defendant started a practice at a house in Vauxhall-bridge-road, which was outside the prescribed radius. The plaintiff thereupon claimed an injunction to restrain the defendant from setting ap in practice in breach of the above-mentioned covenant and in support of his case relied on two instances in which he alleged the defendant had solicited two old patients. The defendant denied that he had solicited any of his old patients; he had only attended one at her express written request and the other was a personal friend on whom he happened to call and at her request he gave her a prescription and received no fee for doing so. The defendant also deposed that at the time of the sale of his practice he offered to agree not to set up in practice within two miles if the plaintiff agreed that he might visit patients within the two miles if requested without restriction, and the defendant alleged that he expressly pointed out to the plaintiff that under the proposed arrangement he should be entitled to attend the plaintiff's next-door neighbour, if requested, 